\title{
Authorities Perspectives Towards the Implementation of Shariah-Compliant Hotel in Malaysia
}

\author{
Azizah Musa ${ }^{1}$, Suhaila Abdul Kadir ${ }^{1}$, Mazne Ibrahim $^{1}$, Norzaliha Jusoh ${ }^{1}$, Siti Nurzahira Che Tahrim ${ }^{1} \&$ \\ Noormariana Mohd Din ${ }^{1}$ \\ ${ }^{1}$ Faculty of Entrepreneurship \& Business, Universiti Malaysia Kelantan, Kampus Kota, Kelantan, Malaysia \\ Correspondence: Azizah Musa, Faculty of Entrepreneurship \& Business, Universiti Malaysia Kelantan, Kampus \\ Kota, Pengkalan Chepa, 16100 Kota Bharu, Kelantan, Malaysia.
}

Received: May 1, 2019

doi:10.5430/rwe.v10n2p10
Accepted: June 1, 2019

Online Published: July 7, 2019

URL: https://doi.org/10.5430/rwe.v10n2p10

\begin{abstract}
Islamic products and services have high contribution to the economy recently. This contribution has inspired Malaysia to set its mission to become a global halal hub. Halal hub generally relies on the level of awareness among Muslim particularly the authority in understanding the main concept of Shariah-compliant products and services. This paper will principally discuss on Shariah-compliant hotel industry by elaborating the important criteria from the perspectives of the authority in achieving the Shariah-Compliant hotel status in Malaysia. Focusing on qualitative method, this study used in-depth and open-ended interviews with the authorities namely JAKIM and JAHEAIK. Interviews were recorded, transcribed and analyzed. It is found that JAKIM and JAHEAIK stated very limited criteria to specify a Shariah-compliant hotel. However, through interviews, JAKIM and JAHEAIK have provided some insights on how to fully achieve the Shariah-compliant attributes. This paper is important as it can significantly provide much needed feedback from the authority perspectives for the use of interested industry players.
\end{abstract}

Keywords: authorities, shariah-compliant, Malaysia

\section{Introduction}

The development of the tourism industry shows annual improvements. It contributed 7 per cent of the approximately RM 8.5 trillion per year to the Malaysian economy. With this healthy development, Malaysia should take initiative to discover and control the market needs for this industry. Malaysia nowadays has been leading the Halal tourism industry. Thus, Shariah-compliant hotel is one of the products which can be further developed to cater this growing market. In Malaysia, at federal level, the framework for halal food has been established by authority Malaysian Islamic Development Department (Jabatan Kemajuan Islam Malaysia - JAKIM) and in state level, by state Islamic religious Department such as Islamic Religious Matters of Kelantan (Jabatan Hal Ehwal Agama Islam Negeri Kelantan - JAHEAIK) and these have been accepted locally and internationally. However, despite this global acceptance, a proper framework of Shariah-compliant hotel is not in place and has not been emphasized as a guideline for hoteliers. As at 2015, over 300 hoteliers have taken initiatives to comply with JAKIM Halal certificate scheme. This figure amounted to only 7\% of the total number of hotels in Malaysia. Despite the high demands from Muslim tourists, this tiny percentage definitely represents an under supply. Therefore, it is important to identify from the authority's perspective the criteria in achieving the Shariah-compliant hotel status.

\section{Review of Literature}

\subsection{Global Travel Market for Muslim Tourist}

The Shariah-compliant hotels are one of the newest editions in the conceptual hotel market trend nowadays. According to Azmin, Azhani, Khalifah, Ismail, Salleh \& Zafir (2015), Shariah-compliant hotel is a new innovative and creative services offered by hotels around the world. By looking at the current scenario, Muslims cover $29 \%$ of the world's population, most living in the Middle East. This means that there are around 2 billion potential guests that will be attracted to enjoy the benefit from Shariah-compliant hotels. In the meantime, Halal is the fastest growing industry in Malaysia as well as in other regions whereby consumers looking for the type of travelling that will fulfil their needs and wants which is in accordance with Shariah attributes (Idris \& Wahab, 2015; Aslan Efe \& Efe 2018). Moreover, Mohamad, Yahya, Azer \& Hamzah (2013) highlighted that Malaysia is a safe destination for 
Muslim travellers because it can cater for their special needs. We put a great concern on halal food, halal manufacturers, halal pharmaceuticals, halal cosmetics, halal packaging, halal logistics as well as halal services from all over the world (Idris and Wahab, 2015; Samori and Rahman, 2013; Atici, 2018). In addition, the trend is currently moving towards travelling activities (Salleh, Hamid, Hashim \& Omain, 2014; Artha \& Mulyana 2018) by which Halal friendly travel is becoming one of the fastest growing segments within the travel industry, subsequently Halal friendly facilities are now in growing demand (Samori \& Sabtu, 2014; Salleh, Hamid, Hashim \& Omain, 2014; Bosupeng, 2018).

\subsection{Shariah-Compliant Hotel Concept and Practices}

Shariah-compliant hotel $(\mathrm{SCH})$ is a relatively new concept by which it is known as Islamic hotels that provide services in accordance with Shariah principles (Azmat, Skully \& Brown, 2014; Andrade \& Fiamenghi-Jr 2018). Shariah-compliant hotel can be defined as a hotel that provides services and makes financial transactions based on completely Shariah principles, not limited to serving halal food and beverages but also for health, safety, environment and the benefits on economic aspects of everyone, regardless race, faith or culture (Jurattanasan \& Jaroenwisan, 2014).

In response to the formation of Shariah-compliant hotel in Malaysia, there exist some hotels which serve basic facilities to fulfil the Muslim tourists' needs and known as 'Muslim friendly hotel' (Samori \& Sabtu, 2014; Samori \& Rahman, 2013). Most of this kind of hotels are located in Kuala Lumpur, Selangor, Kelantan and Terengganu. To name few; PNB Darby Park Hotel and Putra Hotel in Kuala Lumpur, UiTM Hotel and Grand Bluewave Hotel in Shah Alam, Raudah Hotel and Perdana Hotel in Kelantan as well as Tabung Haji Hotel in Terengganu. For instance, De Palma Hotel in Ampang, Kuala Lumpur is one of the hotels that comply with the Islamic concept and positions itself as a Shariah-compliant hotel (Sahida, Rahman, Awang \& Man, 2011; Anthony, Osho \& Sen 2017). In addition, the influx of Middle East tourists to Malaysia provides immense opportunities for SCH when these hotels are attractive to these tourists for accommodation which in turn will increase the SCH profits (Salleh, Hamid, Hashim \& Omain, 2014).

\section{Methodology}

The objective of this study is to identify the authority perspectives towards the criteria of SCH. In order to achieve this objective, an in-depth interview was conducted with two authorities which are known as Jabatan Kemajuan Islam Malaysia (JAKIM) and Jabatan Hal Ehwal Agama Islam Negeri Kelantan (JAHEAIK). Two respondents were interviewed covered the open-ended questions during the study. The interviews were recorded, transcribed and categorized within a week. Categories based on relevant themes were established after examination of the data. The data were sorted into categories using key words as codes. Several issues were brought up and discussed in the next section.

\section{Data Analysis and Results}

\subsection{Feedback on Shariah-Compliant Hotel by JAHEAIK and JAKIM}

From the interviews conducted, several issues were highlighted by the respondents from the authority. The detail information and description are presented in Table 1.

Table 1. Information and description

\begin{tabular}{|c|c|c|c|}
\hline No. & $\begin{array}{l}\text { Scope of } \\
\text { discussions }\end{array}$ & JAHEAIK & JAKIM \\
\hline 1 & Functions & $\begin{array}{l}\text { Halal Certification } \\
\text { Consultation } \\
\text { Thorough checks } \\
\text { Monitoring } \\
\text { Withdraw Halal Certification as an } \\
\text { action for Halal non-compliance }\end{array}$ & $\begin{array}{l}\text { Halal certification which includes products from } \\
\text { Malaysia, Thailand, Middle East, Australia and } \\
\text { New Zealand. } \\
\text { Consultation on Shariah-compliant issues to } \\
\text { interested companies. } \\
\text { Coordinate monitoring for each state to act. } \\
\text { Periodic ambush to non-compliant companies } \\
\text { based on complaint reports. }\end{array}$ \\
\hline 2 & $\begin{array}{l}\text { Directions } \\
\text { and }\end{array}$ & $\begin{array}{l}\text { No specific directions and instructions } \\
\text { received }\end{array}$ & No specific directions and instructions received \\
\hline
\end{tabular}




\begin{tabular}{|c|c|c|c|}
\hline & \multicolumn{3}{|l|}{ Instructions } \\
\hline 3 & Law and Acts & $\begin{array}{l}\text { Akta Perihal Dalam Negeri on halal } \\
\text { and prohibition of abusing the Halal } \\
\text { logo. }\end{array}$ & KPDNKK Enactment \\
\hline 4 & $\begin{array}{l}\text { Maqasid } \\
\text { Shariah }\end{array}$ & $\begin{array}{l}\text { Maqasid Shariah, particularly in } \\
\text { protecting life and lineage by } \\
\text { prohibiting cases such as murder, rape } \\
\text { and adultery in the hotel is identified as } \\
\text { main guide in structuring } \\
\text { Shariah-Compliant hotel. }\end{array}$ & - \\
\hline \multirow[t]{6}{*}{5} & \multirow[t]{6}{*}{$\begin{array}{l}\text { Attributes of } \\
\text { Shariah-Com } \\
\text { pliant Hotel }\end{array}$} & $\begin{array}{l}\text { Halal Kitchen - no pork, alcohol and } \\
\text { etc. } \\
\text { Praying gears in hotel room (mat, } \\
\text { Al-Quran, Kiblat direction) }\end{array}$ & $\begin{array}{l}\text { Staff has the time and is mandatory to perform } \\
\text { Friday prayers } \\
\text { Availability of Islamic knowledge courses and } \\
\text { the requirement for staff to attend }\end{array}$ \\
\hline & & $\begin{array}{l}\text { Other facilities to fulfil Muslims' } \\
\text { religious needs }\end{array}$ & $\begin{array}{l}\text { Staff has to cover themselves properly, so the } \\
\text { staff has to be Muslim. }\end{array}$ \\
\hline & & & $\begin{array}{l}\text { Staff can perform fasting ritual. } \\
\text { The financial investment must be monitored to } \\
\text { take into account the lawful terms of the } \\
\text { transaction. }\end{array}$ \\
\hline & & & $\begin{array}{l}\text { Playing of music is replaced with playing of } \\
\text { Al-Quran recitation. }\end{array}$ \\
\hline & & & $\begin{array}{l}\text { Small percentage on Shariah non-compliant } \\
\text { investment is allowable but not on food } \\
\text { preparation. }\end{array}$ \\
\hline & & & $\begin{array}{l}\text { The Shariah-compliant hospital attributes can } \\
\text { also be adopted for hotels. }\end{array}$ \\
\hline \multirow[t]{6}{*}{6} & \multirow{6}{*}{$\begin{array}{l}\text { Guidelines } \\
\text { and } \\
\text { Framework }\end{array}$} & \multirow{6}{*}{$\begin{array}{l}\text { No official guidelines } \\
\text { No official framework } \\
\text { However, currently, periodic checking } \\
\text { and monitoring of hotel rooms for non } \\
\text { married couples activities and halal } \\
\text { kitchens are already in practice. }\end{array}$} & No official guidelines \\
\hline & & & No official framework \\
\hline & & & $\begin{array}{l}\text { Requirement to appoint Shariah advisory panel } \\
\text { for hotels }\end{array}$ \\
\hline & & & $\begin{array}{l}\text { Provide criteria guidelines on certain aspects: } \\
\text { organisation, finance, architecture, Kiblat and } \\
\text { washrooms. Then, SIRIM will be called to do } \\
\text { thorough checks. }\end{array}$ \\
\hline & & & $\begin{array}{l}\text { Adoption of SIRIM Standard (Ten Critical } \\
\text { Point) for 'Muslim Friendly' Food to } \\
\text { Shariah-compliant hotel standard. }\end{array}$ \\
\hline & & & $\begin{array}{l}\text { Hotels are not forced to follow the } \\
\text { Shariah-compliant requirements, but once } \\
\text { applied, they must fully comply. }\end{array}$ \\
\hline 7 & $\begin{array}{l}\text { Current } \\
\text { Status }\end{array}$ & $\begin{array}{l}\text { Certification of Halal Kitchen to } 19 \\
\text { hotels in Kelantan as Halal Kitchen is } \\
\text { identified as the major attribute of } \\
\text { Shariah-Compliant Hotel. } \\
\text { Self-proclaimed Shariah-Compliant } \\
\text { hotels include:Perdana Hotel } \\
\text { (Kelantan), Grand Blue Wave Hotel } \\
\text { (Selangor), De Palma Hotel (Kuala } \\
\text { Lumpur) and Tabung Haji Hotel } \\
\text { (Terengganu). Tabung Haji Hotel's } \\
\text { Shariah Compliant status is certified by }\end{array}$ & $\begin{array}{l}\text { Dismantling the problems in terms of legislation } \\
\text { is in progress to provide enlightenment on } \\
\text { Shariah- compliant to the industry. } \\
\text { The function to certify Shariah-compliant hotel } \\
\text { status has been given to the state's Islamic } \\
\text { councils, but states do not implement officially. } \\
\text { Due to restricted functionality and authority, } \\
\text { JAKIM has presented proposal to enlarge its } \\
\text { jurisdictions and functionality to Vice Prime } \\
\text { Minister in order to take action to Shariah }\end{array}$ \\
\hline
\end{tabular}


Tabung Haji as a special case. non-compliant service providers.

The issues surrounding the law have also been presented to the AG, to formulate and define Shariah-compliant, and the manner that JAKIM can enforce the law without intruding the states' Islamic jurisdictions.

\begin{tabular}{|c|c|c|c|}
\hline 8 & Issues & $\begin{array}{l}\text { Some hotels do not agree with the } \\
\text { attributes of Shariah-Compliant Hotel } \\
\text { It is impossible for the hotels to obtain } \\
\text { Shariah-Compliant status as majority of } \\
\text { the hotels are not complying. } \\
\text { Difficulties in awarding Halal Food } \\
\text { and Halal Kitchen certifications } \\
\text { Shariah-compliant Hotel certification, } \\
\text { if in place, cannot be enforced to all } \\
\text { hotels, but only to those that decided to } \\
\text { get the certification. Therefore, hotels } \\
\text { writing in to obtain Shariah-compliant } \\
\text { status, is more suitable. } \\
\text { There is no law on Halal to enforce. } \\
\text { Halal Act has been proposed but } \\
\text { received objections from non-Muslim } \\
\text { members in the Parliament. }\end{array}$ & $\begin{array}{l}\text { The implementation of Shariah compliant hotel } \\
\text { is under the jurisdiction of the State Islamic } \\
\text { Council. } \\
\text { Restricted functionality and authority by } \\
\text { JAKIM. E.g.: Certification on } \\
\text { Shariah-compliant movie cannot be awarded as } \\
\text { the function falls within states' Islamic councils } \\
\text { For Shariah-compliant hotels, no action can be } \\
\text { taken if they do not comply due to no law is } \\
\text { provided on this matter. }\end{array}$ \\
\hline 9 & $\begin{array}{l}\text { Feedback } \\
\text { from } \\
\text { hoteliers on } \\
\text { Shariah-Com } \\
\text { pliant hotels }\end{array}$ & $\begin{array}{l}\text { Majority give positive response. } \\
\text { However, the implementation initiative } \\
\text { is slow or under discussion. } \\
\text { Self-initiated actions by the hoteliers } \\
\text { include rules that prohibit non-married } \\
\text { couples to stay in the same hotel } \\
\text { rooms, and create common Islamic } \\
\text { facilities to control the Shariah } \\
\text { non-compliant activities, not serving } \\
\text { alcohol, uniforms that are not revealing } \\
\text { the prohibited parts of the body (aurat) } \\
\text { and providing transport to the Mosque } \\
\text { for morning prayer. }\end{array}$ & $\begin{array}{l}\text { A hotel has its own criteria in creating the } \\
\text { Shariah-compliant environment. } \\
\text { De Palma Hotel in Ampang and Kelana Beach } \\
\text { Resort in Negeri Sembilan are recognized by } \\
\text { JAKIM as Shariah-compliant hotels. } \\
\text { Halal and Shariah-compliant status has } \\
\text { marketing power. } \\
\text { Some hotels are not interested because no strong } \\
\text { will power to comply and the profitability is not } \\
\text { expected to increase dramatically. } \\
\text { According to SIRIM record, not many hotels } \\
\text { applied for Muslim Friendly status in } 2013 \text {. }\end{array}$ \\
\hline 10 & $\begin{array}{l}\text { Action Plans/ } \\
\text { Suggestions }\end{array}$ & $\begin{array}{l}\text { Preparation of Shariah-compliant } \\
\text { guidelines for hotels. } \\
\text { Official announcement of the } \\
\text { guidelines. }\end{array}$ & $\begin{array}{l}\text { Cooperate with Tourism Ministry to include } \\
\text { clauses on Shariah-compliant hotel. } \\
\text { To propose the Shariah-compliant hotel } \\
\text { implementation to states' Muftis. }\end{array}$ \\
\hline
\end{tabular}

\section{Conclusion}

Generally, both JAHEAIK and JAKIM are supporting the implementation of Shariah-compliant hotels. However, their level of jurisdictions and authority are different, of which JAHEAIK consumes more power at the State level, while JAKIM has restricted functionality and authority. Although no official guidelines and frameworks on Shariah-compliant hotels are yet in place, both JAHEAIK and JAKIM have their own ways to monitor and provide consultations to the interested hoteliers. It can be concluded that both the authorities are aware on the demand and interest of some hotels in obtaining Shariah-compliant hotel status. Despite of lacking in law, framework and regulations, the consultation and monitoring are already in place. There are several issues that need to be ironed out before the certifications of Shariah-compliant hotels can be realized officially.

Therefore, recommendations of guidelines and framework for Shariah-compliant hotels are very relevant. Future studies can also include the possibility of providing enabling environment through law and regulations, because it is 
very crucial for the smooth implementations of Shariah-compliant hotel. As the implementations of Shariah-compliant hotel is by choice and not forced to every hotels, the effort should not be prevented by non-Muslim community in Malaysia. The awareness, acceptance, level of compliance and will power can also be areas to study, from the perspective of hoteliers and customers.

\section{References}

Andrade, A. F., \& Fiamenghi-Jr, G. A. (2018). Sheltered Children's Psychological Suffering and Carers' Lack of Training: Observations from a Brazilian Sheltered Home. International Journal of Social Sciences Perspectives, 3(1), 34-37. https://doi.org/10.33094/7.2017.2018.31.34.37

Anthony, M., Osho, G. S., \& Sen, L. (2017). An Econometric Planning Model of Urban Forestry as a Measure of Sustainability: A Matrix of Action and Change. International Journal of Sustainable Development, 6(1), 9-32. https://doi.org/10.18488/journal.26.2017.61.9.32

Artha, I. W. B., \& Mulyana, B. (2018). The Effect of Internal and External Factors of Companies on Profitability and its Implications on Stock Price Index of State-Owned Banks. The Economics and Finance Letters, 5(2), 58-71. https://doi.org/10.18488/journal.29.2018.52.58.71

Aslan Efe, H., \& Efe, R. (2018). The Relationship between Academic Procrastination Behaviors of Preservice Science Teachers and Their Attitudes toward Social Media. Journal of Education and e-Learning Research, 5(2), 102-109. https://doi.org/10.20448/journal.509.2018.52.102.109

Atici, G. (2018). Islamic (Participation) Banking and Economic Growth: Empirical Focus on Turkey. Asian Economic and Financial Review, 8(11), 1354-1364. https://doi.org/10.18488/journal.aefr.2018.811.1354.1364

Azmat, S., Skully, M \& Brown, K. (2014). The Shariah Compliance Challenge in Islamic Bond Markets. Pacific-Basin Finance Journal, 28, 47-57. https://doi.org/10.1016/j.pacfin.2013.11.003

Azmin, M., Azhani, N., Khalifah, Z., Ismail, H. N., Salleh, M., \& Zafir, N. (2015). Issues and Challenges in the Development of Shariah Compliant Hotels in Malaysia. Advanced Science Letters, 21(5), 1146-1149. https://doi.org/10.1166/asl.2015.6063

Bosupeng, M. (2018). Leading Indicators and Financial Crisis: A Multi-Sectoral Approach Using Signal Extraction. Journal of Empirical Studies, 5(1), 20-44. https://doi.org/10.18488/journal.66.2018.51.20.44

Idris, J., \& Wahab, N. A. (2015). The Competitive Advantages of Sharia-Compliant Hotel Concept in Malaysia: SWOT Analysis.

Jurattanasan, A., \& Jaroenwisan, K. (2014). The Attribution of Shariah Compliant Hotel in Muslim Countries. Review of Integrative Business and Economics Research, 3, 39.

Mohamad, S. A., Yahya, W. K., Azer, I., \& Hamzah, H. C. (2013). The Opportunities and Challenges to be a Shariah Compliant Hotel: A Case of LKPP De Rhu Beach Resort. Retrieved 5th October 2016, from https://www.scribd.com/The Opportunities and Challenges to be a Shariah Compliant

Sahida, W., Rahman, S. A., Awang, K., \& Man, Y. C. (2011). The Implementation of Shariah Compliance Concept Hotel: De Palma Hotel Ampang, Malaysia. 2nd International Conference on Humanities, Historical and Social Sciences, IACSIT Press, Singapore.

Salleh, N.Z.M., Hamid, A.B.A., Hashim, N. H., \& Omain, S.Z. (2014). The Practice of Shariah-Compliant Hotel in Malaysia. International Journal of Trade, Economics and Finance, 5(1), 26. https://doi.org/10.7763/IJTEF.2014.V5.335

Samori, Z., \& Rahman, F. A. (2013). Towards the Formation of Shariah Compliant Hotel in Malaysia: An Exploratory Study on Its Opportunities and Challenges. WEI International Academic Conference Proceedings, Istanbul, Turkey.

Samori, Z., \& Sabtu, N. (2014). Developing Halal Standard for Malaysian Hotel Industry: An Exploratory Study. Procedia-Social and Behavioral Sciences, 121, 144-157. https://doi.org/10.1016/j.sbspro.2014.01.1116 